\title{
ACTIVE PROCESSES IN USUAL AFFIXATION WORD FORMATION OF THE CONTEMPORARY RUSSIAN LANGUAGE
}

\author{
Tatyana A. Lukankina ${ }^{1}$ \\ Tatyana Yu. Shchuklina ${ }^{2}$ \\ Leyla A. Mardieva ${ }^{3}$ \\ Heike Wapenhans ${ }^{4}$
}

\begin{abstract}
The article is devoted to the study of usual affixation word formation as one of the most important operating mechanisms in the Russian derivation system. The goal of the research is to reveal active processes and main trends in usual affixation word formation of the contemporary Russian language.W.
\end{abstract} Humboldt's work, where the language is considered not only as a product of human activity, but as the activity itself, as well as E.A. Zemskaya's ideas concerning active and creative nature of the Russian word formation as a subsystem of the general language system.The usual affixation word formation is an actively and dynamically developing aspect of the derivation system existing in the contemporary Russian language. News media language actively uses the resources inherent in the system and the norms of the Russian language: neologisms in newspaper texts are primarily generated through the usual derivation models. It has been revealed that the most productive affixation means of the usual innovations generation comprise the following: suffixation, prefixation, zero-suffixation and affixation-like word formation, wherein the most popular one is suffixation. At the present stage of the Russian language development we witness an increase in adaptive function of word formation types. Joining native Russian affixes to the borrowed stems appears to be one the most productive patterns in the contemporary usual affixation word building, where suffixation is the most demanding one. The research results obtained can contribute to the development of the

\footnotetext{
${ }^{1}$ Kazan Federal University. Email: tatiana21@myrambler.ru

${ }^{2}$ Kazan Federal University

${ }^{3}$ Kazan Federal University

${ }^{4}$ Humboldt University of Berlin.
} 
lexical derivatology, lexical semantics, neology, and language stylistics problems. The promising character of elaborating the declared subject is conditioned by the language processes in mass media activation, which will probably require further study of neologization aspects in mass media texts in the nearest future, making possible to explore the functional and pragmatic potential in word formation resources of the contemporary Russian language.

Keywords: usual affixation word formation, patterns of usual affixation word formation, ways of usual affixation word formation, derivational neonominations, mass media language

\section{Introduction}

In recent decades particular attention to word formation aspect of the contemporary Russian language has been observed with a view to activation of derivation processes therein. Domestic and foreign linguistic writings demonstrate various approaches to derivative lexic studies: structuralsemantic [1], [2], linguistic and cultural $[3],[4], \quad$ cognitive [5], [6] and methodological [7], [8].
The study of the communicative aspect in word formation is of particular importance; and neologization in mass media in particular, as it becomes one of the main sources of neologisms establishing. Active derivation processes investigation based on mass media communicative language and being a kind of catalyst for language transformations, helps to identify the most important changes in the word formation system of the Russian language and to trace the trends in usage development as a whole. This determines the urgency of the present work.

The aim of the study is to reveal active processes in usual affixation word building of the contemporary Russian language.

The target of the research is the usual affixation neologisms in mass media texts of the last decade as active word formation processes reflection in the modern Russian language.

The research was carried out on the lexical material of newspaper periodicals. The resource base of the research has become the card file of usual words extracted from Russian periodical newspapers: "Argumenty i Facty", "Itogi”, “Kommersant", "Komsomolskaya Pravda", 
"Moskovskiy Komsomolets", "Novaya

Gazeta", "Sovetskiy sport",

"Rossiyskaya Gazeta", etc.

\section{Methods and methodology}

W. Humboldt's work, where the language is regarded not only as a product of human activity, but as an activity itself [10], E.A.Zemskaya's ideas concerning active and creative nature of the Russian word formation as a subsystem of the general language system [11], together with the presentday Russian word formation theories, presented in the studies of E.S. Kubryakova, A.N. Tikhonov, I.S. Ulukhanov, V.N. Nemchenko, V.V. Lopatin, the scientists of the Kazan linguistic school, served as the theoretical and methodological basis of the present paper.

The research methodology involves application of linguistic description tools with elements of usual derivative units' interpretation, continuous sampling of lexical materials, structural and semantic word formation analysis and contextual analysis - at describing the neologisms operation.

\section{Results and discussion}

The language of newspaper periodicals having recently become a sphere of increased word formation activity abandons in word derivatives made through the usual word formation methods. The following productive patterns of word formation reflecting active processes in the modern Russian language usual affixation word formation have been revealed.

\section{Suffixal derivation model}

Suffixation is one of the most popular ways to form new words in the Russian language.

It is the sphere of suffixation where we can observe more active interaction of 1) the borrowed suffixes both with the Russian and foreign word stems; 2) the Russian suffixes both with the borrowed and original producing stems; 3) stylistically heterogeneous morphemic parts: book suffixes and stems in the original stylistically reduced words, and vice versa.

Progress in productivity of several suffixal patterns is noted within the following lexical groups:

1. Names of persons with the meaning of the characteristics bearer (subject or processual) formed by: 
A) Foreign language productive book suffixes -ист, -атор, -ант (-ist, ator, -ant) in conjunction with the foreign and Russian stems: lobbyist, performancist, Nashiist (member of "Nashi” (Ours) organization), podpisant, nominant, nominator, kommunikator, and monetizeator;

B) Through the Russian suffixes -ник, -чик/-щик, -ец/-ов/-овец (-nik, chik/-schic, -ets/-ov/-ovets) from foreign stems: offshornik, internetchik, piarovets, spamschik. The semantics of this word subgroup is substantially expanding: in addition to naming of the person by his occupation or interest, they can have the meaning of 'a supporter, a follower of anything': gosudarstvennik (state authorities supporter), LDPRovets (the supporter of LDPR party), EGEshnik (a person who has passed the Uniform State Exam) etc. The forming stem here is often a proper noun combined with the suffix -ец(-овец) (ets(-ovets): obamovets, poroshenkovets, zyuganovets, etc.

2. Names with the meaning of an attribute formed through the Russian suffix-ск, -ов/-овск, -н (-sk, -ov/-ovsk, n) combined with the borrowed stems: schengenskiy, uzerskiy, onlainovyi, piarovskiy, kreativnyi.
3. Action designations formed by verbal suffixes -ирова, -ова, -и (-irova, ova, -i): a) from the borrowed stems of common nouns: brendirovat', prodyusirovat', kastingovat', offshorit'; b) from the stems of proper nouns: gaidarit', chubaisit', naval'nichat', petrosyanit'.

4. The names of abstract semantics with the Russian suffixes: ость/-есть, -ств(о)(-ost, -est, -stv(o) and borrowed ones: -изм, -инг, (-ism, -ing), their occurrence is connected with the increase in producing stems due to the expansion of colloquialism and jargonism stems existing in the Russian language, foreign stems as well as the use of basic proper names: pokazushnost',nenashest', zhestokism, lobbism, spamerstvo, premyerstvo, putinism, trampism, marketing, franchising, etc. Suffix -ing- joining the Russian stem (or the stem long ago adapted to the system of the Russian language) performs the function of a game and bears emotional and evaluating character: pokupping (shopping), tovarring, svaling, obyegoring (screwing over), etc.

5. Designations of socially significant reality processes with the foreign suffixes -ациј(а) and -изациј(а) 
(-atsiya, -izatsiya ) derived from a) the borrowed common nouns with the meaning of their baseline: dollarizatsiya, fermerizatsiya, kompyuterizatsiya; b) from the personal name stems and expressing the meaning of the process or phenomenon conditioned by the given object activity or influence. Such derivatives acquire expressive and evaluative but often negative connotation being formed under the influence of both motivating semantics and context (mavrodizatsiya, chubaisizatsiya, navalnizatsiya).

6. Generated from the Russian stems substantives with the suffixes ух(a), -ак, -ач, -ан, -еж, -няк, -щин(а) (ukh(a),-ak,-ach,-an,-ezh, -nyak, shchin(a)) generally with a pejorative evaluation, and becoming active in a colloquial sphere. Among them:

- names of abstract semantics: razvlekukha, golodukha, zhitukha, otkhodnyak, galdyosh;

- name of persons: zvezdach, zvezdun, bandyugan, viagrik, stervoza, vypivokha, glupar, parnyaga;

- designation of phenomena, events, states (bespredel'shchina, mitingovshchina, obydyonshchina, anomal'shchina), neologisms occupying a special place among them, being formed from the proper names of the prominent contemporary figures: luzhkovshchina, kadyrovshchina, poroshenkovshchina, obamovshchina, trampovshchina.

\section{Prefixal derivation model}

One of the productive patterns in the modern word formation is joining the Russian native prefixes to borrowed stems. In the recent days the bookish sphere become rich in a number of neologisms with foreign prefixes анти-, контр- (anti-, kontr-) and the meaning of negation and antithesis: antikrizisnyi, antipremiya, kontrevolutsiya, kontrelita; псевдо-, квази- (psevdo-, kvasi-) - with the semantics of non-genuine and false: psevdoparad, psevdosmysl, kvaziperevorot, kvaziekspertiza, kvazielitnyi; супер-, мега- (super-, mega) - with size-estimating and attitudinal meaning representing the quantitative expression: superdorogoi, superkomfortnyi, supermudrost', megasensatsiya, megagory, megaegzoticheskiy; нано- (nano-), indicating the attitude to nanotechnology: nanoprotezy, nanochastitsa, nanoasfalt; pe- (re-) with 
the meaning of the previous action iteration: renovatsiya, repost.

One may say, that we observe the first signs of emerging a new negative prefix нон- (non-), which is met in few words with foreign stems: nonfaktor, nonfakt, nonstandart, nonfigurativnyi.

The following colloquial prefixes have become active: c- (s-): skreativit', spionerit', srossiyanit'; от- (ot-) : otyekhat' (to leave for a while), otkserit', ottelefonit'; пере- (pere-): perepiarit', perestakhanovit' (from Stakhanov), pereshilit' ( from "shilo" - bodkin), peremylit' (from "mylo" - soap) with the meaning "to surpass in some aspect anybody (anything), who (that) is called a motivating base"; до- (do-): dopodumat', donumerovat'; об- (ob-): obshutit'; при- (pri-): prifantazirovat', prikupit'; про- (pro-) with the meaning of adherence to something (most often to any political regime): prorossiyskiy, prozapadnyi, proamerikanskiy; paz(raz-) with the meaning of eliminating the previous activity results: razvidet', razmusorit'.

\section{Word formation pattern of zero suffixation}

Zero suffixation is one of the productive ways of nominal word formation. The given pattern functions both in spoken and jargon speech. Within the period under study the nouns (mostly related to the colloquial and slang lexicon) with the following derivational meanings, appear to be the most demanding: "abstract action" (vrub, otgib, otkat, razogrev, vzlom (comp.), oblom , otkaz (v otkaze), dozvon, prikol, razrul); "the person": "the person towards action" (garant); "the person - attribute bearer" (nelegal, infantil, neformal, virtual); "the person presentive attribute bearer" (super chel, kach, chyos, fan); "the object - attribute bearer" (chernopol, beznal); "abstractive attribute" (beles', chern').

\section{Affixoid word formation pattern}

In recent decade activization of several borrowed affixes has been accompanied by the enhancement of their expressiveness and evaluativity. Thus, a new suffixoid -geit (gate) borrowed from the English language and meaning "political scandal" has become widely used in mass media in neologisms, particularly in those created from the proper names - toponyms and 
names of key figures prominent in certain historical periods: Altaigeit, Irangeit, Obamageit, Kuchmageit.

In many mass media innovations the prepositional element нано- (nano-) no longer indicates a minimal size; it implicates negative evaluation of speculative activities in relation to new technologies: nano-chto-to-tam (nanosomething), nanoscandal, nanodeltsy, nanoChubais, nanorezultaty.

Alongside with that, estimatively neutral neologisms turn up to be also efficient, for instance, those with the element -мейкер (-meiker): marketmeiker, imidzhmeiker, klipmeiker, shoumeiker, etc.; with the element медиа- (media-): mediabusiness, mediaaktivy, mediaholding, mediamagnat, mediapokupka, mediaprostranstvo, mediarynok, mediaset' and with the element -мания (maniya): kinomaniya, pepsimaniya, shokoladomaniya.

\section{Summary}

Active processes in usual affixation word formation are associated with general linguistic changes caused by social and economic, political transformations which have occurred in the Russian society within the late XX and early XXI centuries, particularly, the so-called democratization and liberalization of the language and weakening of normative rules in linguistic unit formation and usage, jargonization of the modern Russian language and a sharp increase in the flow of English borrowings.

News media phraseology actively uses the resources inherent with the system and the norms of the Russian language: neologisms in newspaper texts primarily generated by usual derivational patterns employing the effective word formation affixes. In disregard of the avalanche number of new derivational naming units, composition of productive formants remains virtually unchanged: native speakers prefer effective patterns already existing in the language system. On the whole, modern usual word-formation remains within the frames of traditionally common ways of word derivation.

The most productive affixation means of usual innovations formation comprise: suffixation, prefixation, zerosuffixation and affixoid word formation, wherein suffixation turns up to be the most popular tool. 
One of the most efficient patterns of modern usual word formation is joining Russian native affixes to the borrowed stems, where the suffixes are the most demanding. At the present stage of development word-formative types have become more adaptive. The system of affixation word formation types is so firm that it can easily recycle borrowed stems forming derivatives with the Russian affixes. That being said, Russian stems are actively involved in usual word formation, i.e. in forming new words according to the efficient patterns. Such words represent a systemically important property of the Russian word formation: derivational morphology according to productive patterns is contextually conditioned and situation dependent. Moreover, in recent decade we observe a noticeable activation of foreign language affixes the most productive of which being the prefixes.

With a view to the personal criterion increase word formation in mass media text performs not only nominative but also expressive and evaluating function, the latter being more significant for present-day journalism. Neologisms are employed as an effective means to make the text more expressive and, what is more, they possess evaluativity or tend to acquire it, as their evaluative nature is syntagmatically and contextually conditioned. Word formation turns into effectual axiological aid and one of the tools for social assessment in media personalities' oral activity.

\section{Conclusions}

Thus, the presented research has revealed that usual affixation word formation is one of the most important functional and dynamically developing mechanisms in the Russian derivation system.

From the theoretical point of view, the work is of interest in terms of clarifying scientific ideas about word formation as a dynamic aspect of the Russian language. The results of the research can contribute to the development of problems of lexical derivatology, lexical semantics, neology and language stylistics.

The promising character of the declared subject is conditioned by activation of language processes in mass media, which in the nearest future will probably require further studies concerning word creation aspects in mass media texts making it possible to 
explore the functional and pragmatic potential in word formation resources of the contemporary Russian language.

\section{Acknowledgements}

The work is performed according to the Russian Government Program of Competitive Growth of Kazan Federal University.

\section{Bibliography}

V. Fatkhutdinova, "Word-formation family in derivation-semantic space of differently structured languages", Journal of Language and Literature, vol. 6, № 3, is.1, pp. 76-80, 2015.

S. Ilyasova, "Denominative verbs as a result of motivation and pseudomotivation", Philology and culture, 2016, № 4(46), pp. 44-49, 2016.

I. Erofeeva, "Nominalization in linguocultural paradigm of chronicles", Life Science Journal, vol. 11, № 11, pp. 438-442, 2014.

T. Vendina, "Russian language world picture through the prism of word formation”. Moscow, 1998.
I. Evseeva, "Cognitive modeling of the Russian language word formation system”, Kemerovo, 2011.

E. Gorobets, R. Kulsharipova, M. Novak, "Speech disorders in patients withcognitive impairment caused by neurogenerative diseases: an overview", Journal of Language and Literature, vol. 7, is.2, pp. 177-180, 2016.

M. Hashemi, "The impact(s) of teaching word-formation knowledge in increasing the nursing students' reading comprehension skill”, Academic Research International, vol. 1, № 1, pp. 52-60, 2011.

D. Martyanov, E. Gorobets, M. Novak, "The category of aspect in the Russian language: teaching problems", Modern Journal of Language Teaching Methods, SI, Nov, pp. 203-206, 2016.

V. Humboldt, "Selected works in linguistics”, Moscow, 1984.

E. Zemskaya, "Word formation as an activity", Moscow, 2009 